\title{
Biosynthesis of the Transferrin Receptor in Rabbit Reticulocytes
}

Timothy M. Cox, Martin W. O'Donnell, Philip Aisen, and Irving M. London

Harvard-Massachusetts Institute of Technology Division of Health Sciences and Technology and Department of Biology, Massachusetts Institute of Technology, Cambridge, Massachusetts 02139;

Departments of Physiology and Biophysics and Medicine, Albert Einstein College of Medicine, Bronx, New York 10461

\section{Abstract}

These studies were performed to determine whether the reticulocyte can synthesize its own transferrin receptor and, if so, whether synthesis is subject to translational control by intracellular heme.

Reticulocytosis (20-35\%) was produced by bleeding rabbits and the washed cells were incubated for $1-4 \mathrm{~h}$ at $37^{\circ} \mathrm{C}$ in buffered nutritional medium containing $\left.\mathrm{L}-\mathrm{I}^{35} \mathrm{~S}\right]$ methionine. After washing and detergent lysis in the presence of protease inhibitors, supernatant reticulocyte extracts were analyzed for transferrin receptors by immunoprecipitation with specific ovine receptor antibody raised against denatured rabbit transferrin receptor. Immunoprecipitates were analyzed by SDS-gel electrophoresis and fluorography. Antibody, but not preimmune sheep immunoglobin, consistently precipitated a ${ }^{35} \mathrm{~S}$-labeled protein with an $\boldsymbol{M}_{\mathrm{r}}$ of 90,000 (reduced), coincident with bona fide receptor subunits purified by ligand-affinity chromatography.

Incorporation of radioactive methionine was exclusively associated with receptor in reticulocyte stroma, and nascent receptor was not detected on free polyribosomes. Incorporation of radioactivity in the receptor moiety accounted for $0.1-0.2 \%$ of total incorporation into TCA insoluble cell protein. Treatment of the cells with $40 \mu \mathrm{g} / \mathrm{ml}$ cycloheximide markedly inhibited amino acid incorporation into the receptor, thus indicating de novo synthesis of receptor protein. On treatment of reticulocytes with 4,6 dioxoheptanoate to induce heme deficiency by diminishing the formation of intracellular heme, synthesis of the receptor was inhibited by $>\mathbf{5 0} \%$; synthesis was restored to control rates on addition of $50 \mu \mathrm{M}$ exogenous hemin.

These findings indicate that the reticulocyte retains receptor mRNA and that synthesis of the receptor in erythroid cells is subject to translational regulation by intracellular heme.

\section{Introduction}

Immature erythroid cells possess abundant receptors for the plasma iron-binding protein transferrin (1). The presence of these receptors allows iron to be incorporated into these cells and to be used in the synthesis of heme (2). Hemoglobin synthesis continues during the maturation of erythroid cells, and persistent expression of transferrin receptors on the reticulocyte surface facilitates rapid iron uptake, even after these cells are discharged

Dr. Cox's present address is Department of Medicine, Royal Postgraduate Medical School, London, W.12, England.

Received for publication 14 March 1985 and in revised form 24 June 1985.

J. Clin. Invest.

(c) The American Society for Clinical Investigation, Inc. 0021-9738/85/12/2144/07 \$1.00

Volume 76, December 1985, 2144-2150 into the circulation (3). The importance of functional transferrin receptors for maintenance of heme production thus raises the possibility that reticulocytes may also retain the ability to synthesize their own receptors.

Active protein synthesis by immature erythroid cells is dependent upon intracellular heme (4). Extensive studies with reticulocyte preparations in vitro have shown that in heme deficiency a latent protein kinase, which phosphorylates the initiation factor eIF-2, is activated (5). The phosphorylated eIF-2 sequestrates another factor responsible for its recycling, thereby inhibiting polypeptide chain initiation on ribosomes. As a consequence, protein synthesis ceases (6). This translational control process obtains for the synthesis of reticulocyte proteins generally $(7,8)$.

The condition that most commonly leads to intracellular heme depletion in erythroid tissue is iron deficiency. In such circumstances, the additional question is raised as to whether synthesis of the transferrin receptor itself is influenced by heme deficiency in immature erythroid cells. Active synthesis of receptors in these cells could be advantageous, since it might facilitate the rapid recovery of hemoglobin synthesis during periods of repletion of iron stores. Accordingly, experiments were carried out to determine whether reticulocytes synthesize transferrin receptors and, if so, whether this process is subject to translational control by intracellular heme.

\section{Methods}

Cells. Reticulocytosis was induced in male rabbits weighing $2.5-4.5 \mathrm{~kg}$ by repeated phlebotomy. $20-50 \mathrm{ml}$ of blood was drawn from the ear 23 times weekly. The hematocrit was maintained at $25-35 \%$, with a reticulocyte count of $15-40 \%$ as judged by staining with New Methylene Blue N (B-4631, Sigma Chemical Co., St. Louis, MO). The cells, hereafter designated reticulocytes, were washed thrice in reticulocyte saline (RS) ${ }^{1}$ $(0.13 \mathrm{M} \mathrm{NaCl}, 0.0074 \mathrm{M} \mathrm{MgCl}$, and $0.005 \mathrm{M} \mathrm{KCl}$ buffered to $\mathrm{pH} 7.4$ with $0.01 \mathrm{M} \mathrm{Na}$-Hepes) and collected by centrifugation in a bench centrifuge. The buffy coat was carefully aspirated after each cycle. In some experiments, leukocytes and platelets were removed by elutriation through a column of cellulose matrix equilibrated in RS (9).

Preparation of transferrin. Transferrin was prepared from rabbit serum by the method of Baker et al. (10). The protein was further purified by passage through columns of DEAE-Affi-Gel Blue (Bio-Rad Laboratories, Richmond, CA). When applied to this gel in $0.02 \mathrm{M}$ sodium phosphate at $\mathrm{pH} 8.0$, the transferrin did not bind and was recovered in the void fractions. Electrophoretic purity after this step was $>95 \%$. The extinction coefficient of a $1 \% \mathrm{wt} / \mathrm{vol}$ solution of the iron-saturated protein at 280 $\mathrm{nm}$ was taken to be 14.0.

Isolation of transferrin receptor. Transferrin receptor was purified from reticulocyte stromal membrane by affinity chromatography on columns of immobilized ligand. $40 \mathrm{ml}$ of washed, packed reticulocytes were lysed in 10 vol of ice-cold deionized $\mathrm{H}_{2} \mathrm{O}$. After sedimentation at 10,000 $g$ for $20 \mathrm{~min}$, the membrane pellet was washed in $0.13 \mathrm{M} \mathrm{NaCl}-0.01 \mathrm{M}$

1. Abbreviation used in this paper: RS, reticulocyte saline. 
Na-Hepes, $\mathrm{pH} 7.4$, and recentrifuged. The cycle was repeated until the membrane pellet was light pink. The stroma was suspended in $5 \mathrm{vol}$ of buffer, and Triton X-100 was added to a final concentration of $1 \%$ wt/ vol. The clarified mix was swirled on ice for $30 \mathrm{~min}$ and then centrifuged at $105,000 \mathrm{~g}$ for $1 \mathrm{~h}$ at $2^{\circ} \mathrm{C}$. The resulting supernatant was used for isolation of receptor.

Affinity matrix was prepared by linking rabbit transferrin covalently to agarose gel with the use of cyanogen-bromide-activated Sepharose 4B (Pharmacia Fine Chemicals, Piscataway, NJ). The final concentration of immobilized protein was $2 \mathrm{mg} / \mathrm{ml}$ of swollen gel. The gel was treated with $0.5 \% \mathrm{wt} / \mathrm{vol}$ acetic acid and then equilibrated in Hepes-Saline buffer containing $0.1 \% \mathrm{wt} / \mathrm{vol}$ Triton $\mathrm{X}-100$ before use. The gel was then treated with fresh neutral ferric nitrilotriacetate $(0.5 \mathrm{ml}$ of a $200-\mu \mathrm{M}$ solution, $4: 1$ chelate/metal ratio, per milliliter of gel) to saturate the ligand before chromatography.

Affinity chromatography was carried out at room temperature using a 2-ml bed volume of transferrin-Sepharose. Supernatant extract of reticulocyte membranes was passed through the column at $40 \mathrm{ml} / \mathrm{h}$ and followed by $50 \mathrm{ml}$ of buffer containing $0.5 \mathrm{M} \mathrm{NaCl}$ and $0.1 \%$ Triton X100. The column was reequilibrated with $0.01 \mathrm{M}$ Hepes, $0.13 \mathrm{M} \mathrm{NaCl}$, and $0.1 \%$ Triton $\mathrm{X}-100$. Transferrin receptor was eluted with a five bed volume pulse of $0.5 \% \mathrm{wt} / \mathrm{vol}$ acetic acid in $0.1 \%$ Triton X-100 and immediately neutralized by addition of $1 \mathrm{M} \mathrm{Na-Hepes,} \mathrm{pH}$ 7.5. The eluted protein was concentrated by precipitation with TCA in the presence of sodium deoxycholate (11). After centrifugation, the precipitate was washed in diethylether and treated with $5 \mathrm{ml} \mathrm{2:1} \mathrm{vol/vol} \mathrm{acetone/methanol}$ overnight at $-20^{\circ} \mathrm{C}$. The final pellet of white protein was dissolved in hot 9-M urea. The estimated yield was $1-2 \mathrm{mg}$.

Transferrin receptor antibody. Receptor antibody was raised in a 45$\mathrm{kg}$ sheep. The animal received $0.2 \mathrm{ml}$ Bordetella pertussis antigen (Difco Laboratories, Detroit, MI) subcutaneously at two sites and before immunization was bled $100 \mathrm{ml}$. Denatured receptor $(200-400 \mu \mathrm{g})$ in Freund's complete adjuvant (Difco Laboratories) was then injected intradermally at 10 sites and subcutaneously at 4 sites. This procedure was repeated at 3 and $5 \mathrm{wk}$ and finally at $9 \mathrm{wk}$. $10 \mathrm{~d}$ after the last immunization, the animal was exsanguinated and the serum stored at $-70^{\circ} \mathrm{C}$.

IgG was prepared from preimmune and immune sera by ammonium sulfate fractionation and chromatography on DEAE-Affigel Blue (12). Immunoaffinity gel was made by linking ovine IgG to $\mathrm{CNBr}$-Sepharose 4B; control gel was prepared in parallel using preimmune IgG. These gels contained $1.5 \mathrm{mg}$ immunoglobulin/ml packed beads. Immunoaffinity chromatography was carried out at room temperature in the presence of $0.01 \mathrm{M} \mathrm{Na}$-Hepes, $0.13 \mathrm{M} \mathrm{NaCl}$, and $0.1 \%$ Triton X-100, pH 7.4. Aliquots of reticulocyte extracts were applied slowly to $0.5 \mathrm{ml}$ of IgGSepharose in 3-ml econocolumns (Bio-Rad Laboratories). After $5 \mathrm{~min}$, the columns were washed through with 3-column vol of buffer at a flow rate of $\sim 10 \mathrm{ml} / \mathrm{h}$ and the total eluate was collected for analysis. Rabbit anti-sheep IgG was prepared from the serum of a rabbit immunized with preimmune IgG and affinity purified by acid-elution after absorption on ovine IgG immobilized on cyanogen bromide-activated Sepharose 4B. Two-dimensional immunodiffusion showed a single major precipitation line with reactions of identity against whole sheep serum and purified $\operatorname{lgG}(13)$.

Receptor antibody was further purified by affinity absorption on erythroid membranes. All affinity procedures were carried out in $0.13 \mathrm{M}$ $\mathrm{NaCl}-0.01 \mathrm{M} \mathrm{Na}-\mathrm{Hepes}, \mathrm{pH} 7.4$, containing EDTA (10 mM), aprotinin $(100 \mathrm{IU} / \mathrm{ml})$ azide $(0.02 \%)$, and phenylmethylsulfonylfluoride $(0.5 \mathrm{mM})$ at the indicated final concentrations, to inhibit proteases and microbial growth. $\operatorname{lgG}(10 \mathrm{mg} / \mathrm{ml})$ or a 1:1 dilution of serum was first treated with $2 \mathrm{ml}$ of $2 \mathrm{mg} / \mathrm{ml}$ transferrin-Sepharose $4 B$ for $2 \mathrm{~h}$ at room temperature to remove any contaminating antibodies directed against rabbit serum transferrin. The antibody solution was then tumbled overnight at $4^{\circ} \mathrm{C}$ with normal erythrocyte stroma prepared from a rabbit that had not been previously bled. The membranes were removed by centrifugation at $10,000 \mathrm{~g}$ and the supernatant was then absorbed by identical treatment with washed stroma prepared from rabbit reticulocytes. The stroma was harvested by centrifugation and washed likewise three times in Hepes- saline and once in $0.6 \mathrm{M} \mathrm{NaCl}$ buffered to $\mathrm{pH} 7.4$ with $0.01 \mathrm{M} \mathrm{Na}$ Hepes.

Affinity purified antibody was removed from stromal receptors by treatment with $10 \mathrm{vol}$ of $1 \% \mathrm{vol} / \mathrm{vol}$ acetic acid. After $10 \mathrm{~min}$, the mix was centrifuged at $10,000 \mathrm{~g}$ and the supernatant, containing antibody, was neutralized by the addition of $1.5 \mathrm{M}$ Tris- $\mathrm{HCl}, \mathrm{pH} 8.8$. After neutralization, contaminating stromal proteins are denatured and precipitated so that specific antibody may be prepared from the eluate after further centrifugation. Purified antibody was concentrated by dialysis against saturated ammonium sulfate. The precipitated material was collected by centrifugation, dissolved in water, and equilibrated in Hepes-saline by further dialysis. At an assumed extinction coefficient of 14.0 for a $1 \%$ $\mathrm{wt} / \mathrm{vol}$ solution at $280 \mathrm{~nm}$, the final yield of antibody was $\sim 8 \mathrm{mg}$, after clarification by further centrifugation at $12,000 \mathrm{~g}$. Immunodiffusion against rabbit anti-sheep IgG confirmed the presence of ovine immunoglobulin, which was judged to be $>80 \%$ pure by electrophoresis.

Analysis of labeled transferrin receptor. For labeling, reticulocytes were incubated as a $20-33 \%$ suspension in $R S$ at $37^{\circ} \mathrm{C}$ in the presence of $1 \mathrm{mg} / \mathrm{ml}$ iron-saturated transferrin at $0.1 \% \mathrm{D}$-glucose. Isotopes were obtained from New England Nuclear, Boston, MA. Except where indicated, the incubation mixture also contained $20 \mathrm{~L}$-amino acids, each at a final concentration of $50 \mu \mathrm{M}$. Cell suspensions were agitated to maintain oxygenation and avoid clumping. In experiments with $\mathrm{L}-\left[{ }^{35} \mathrm{~S}\right]$ methionine (NEG-004T), label $(>1,000 \mathrm{Ci} / \mathrm{mmol})$ was added at $0.4-1.5 \mathrm{mCi} / \mathrm{ml}$ cells in the presence of the 19 unlabeled L-amino acids. Overall protein synthesis was determined by counting the TCA-insoluble radioactivity incorporated into total cell protein (14). Hemin for addition to the mix was dissolved in $1 \mathrm{M} \mathrm{NaOH}$ and brought to $\mathrm{pH} 7.4$ with Hepes before use; control incubations without hemin contained equivalent amounts of buffer and base. Intracellular heme deficiency was induced in intact cells by incubation with 4,6 dioxoheptanoate added as a neutral solution in RS (15).

Reticulocytes were surface labeled in situ with ${ }^{125}$ I (NEZ-033L, 17 $\mathrm{Ci} / \mathrm{mg}$, reductant free) using Iodo-Gen reagent (Pierce Chemical Co., Rockford, IL), and following the procedure were recommended by the manufacturer. $1 \mathrm{ml}$ of reticulocytes was incubated at $25^{\circ} \mathrm{C}$ with $100 \mu \mathrm{Ci}$ ${ }^{125} \mathrm{I}$ in $0.01 \mathrm{M} \mathrm{Na}$ phosphate, $\mathrm{pH} 8.5$, and $0.135 \mathrm{M} \mathrm{NaCl}$ in an IodoGen-coated glass tube (Pierce Chemical Co.). After swirling for $30 \mathrm{~min}$, the cells were recovered by centrifugation and washed twice in RS. The final pellet was solubilized in $2 \mathrm{ml}$ buffer containing $1 \%$ Triton X-100, $10 \mathrm{mM}$ EDTA, $1 \% \mathrm{vol} / \mathrm{vol}$ aprotinin (Sigma Chemical Co.), and $1 \mathrm{mM}$ phenylmethylsulfonylfluoride. The 105,000-g supernatant was then analyzed by immunoprecipitation.

Washed reticulocytes were labeled with ${ }^{125}$ I-transferrin after incubation in RS for $20 \mathrm{~min}$ at $37^{\circ} \mathrm{C}$ to release cell-associated transferrin. ${ }^{125}$ I-transferrin $\left(10^{5} \mathrm{cpm} / \mu \mathrm{g}\right)$ was prepared by the lactoperoxidase technique (16) and $20 \mu \mathrm{g}$ was incubated with $1 \mathrm{ml}$ of packed cells for $1 \mathrm{~h}$ at $0^{\circ} \mathrm{C}$ in a final volume of $2 \mathrm{ml}$. The mixture was made $2 \% \mathrm{wt} / \mathrm{vol}$ in Triton X-100 and centrifuged at $30,000 \mathrm{~g}$ for $60 \mathrm{~min}$ to obtain a detergent extract of reticulocyte-associated transferrin for analysis by gel-permeation and immunoaffinity chromatography.

Incubations for metabolic labeling studies were stopped after 1 to 6 $\mathrm{h}$ by dilution in $10 \mathrm{vol}$ of ice-cold RS and rapid centrifugation of the cell pellets. The pellets were washed twice by centrifugation before lysis in detergent. It was found that the combination of $1 \% \mathrm{wt} / \mathrm{vol}$ Triton X$100,1 \% \mathrm{wt} / \mathrm{vol}$ sodium deoxycholate, and $0.1 \% \mathrm{wt} / \mathrm{vol}$ SDS reduced nonspecific precipitation, and in buffer containing $150 \mathrm{mM} \mathrm{NaF}, 10$ $\mathrm{mM}$ EDTA, and $20 \mathrm{mM}$ Tris- $\mathrm{HCl}$, pH 7.5, rapidly solubilized the pellets. Typically, $100-300 \mu \mathrm{l}$ of cells were taken up in $1 \mathrm{ml}$ of solubilization buffer and centrifuged at $105,000 \mathrm{~g}$ at $2^{\circ} \mathrm{C}$. The high-speed supernatant was used for subsequent immunoprecipitation. Aliquots of extracts were treated with $50 \mu \mathrm{g}$ of specific ovine IgG for $14 \mathrm{~h}$ on ice in a final volume of $1.4 \mathrm{ml}$. The second stage was completed by addition of 5-10-fold excess of affinity pure rabbit anti-sheep IgG and, after mixing at room temperature, the mixture was left for an additional $2 \mathrm{~h}$ on ice.

Immunoprecipitates were harvested by centrifugation at $12,000 \mathrm{~g}$ for $15 \mathrm{~min}$ and washed five times by dispersing in solubilization buffer 
and recentrifuging. The precipitates were taken up at $90^{\circ} \mathrm{C}$ in $45 \mu 19 \mathrm{M}$ urea and $10 \mu \mathrm{l}$ beta mercaptoethanol, and, after addition of $55 \mu \mathrm{l}$ of twice-concentrated sample buffer containing SDS, were boiled for $5 \mathrm{~min}$.

Immunoprecipitated receptor was analyzed by gel electrophoresis in $7.5 \%$ polyacrylamide slabs according to Laemmli (17). Gels were stained routinely with Coomassie Blue and after drying were subjected to radioautography using Kodak X-Omat XAR-5 film (Eastman Kodak Co., Rochester, NY). ${ }^{35}$ S-labeled proteins were detected fluorographically using Enhance (New England Nuclear). The migration of labeled proteins of interest was compared with standards (Bio-Rad Laboratories) by overlaying radioautograms onto the original gel. Radioactivity in TCA-insoluble extracts on filters and solubilized immunoprecipitates was measured in a scintillation counter after decolorization with hydrogen peroxide.

\section{Results}

The material isolated by affinity chromatography of reticulocyte extracts on transferrin-Sepharose has many of the characteristics reported for transferrin receptors, including the ability to bind repeatedly to the gel in the presence of low concentrations of Triton X-100, after desalting (not shown). To determine whether the antibody raised against this protein component after antigen denaturation could recognize native receptors on the reticulocyte surface, gel permeation chromatography was used to prepare solubilized receptors labeled with ${ }^{125}$ I-transferrin (Fig. 1). Three peaks of radioactivity were detected after Sephadex G-200 chromatography of detergent extracts prepared from reticulocytes following incubation with ${ }^{125} \mathrm{I}$-transferrin at $0^{\circ} \mathrm{C}$ : a form eluting close to the void volume (peak 1); a peak coincident with free transferrin and appearing just before hemoglobin (peak 2); a small peak appearing after one bed volume and probably representing free iodide. Aliquots of peaks 1 and 2 were applied to columns of ovine IgG-Sepharose and the amount of bound radioactivity was quantified (Table I).

Significant retention of ${ }^{125}$ I-transferrin was only demonstrated in experiments where samples from the high molecular weight peak 1 were applied to columns of IgG-Sepharose prepared from serum obtained after immunization with receptor. Since significant retention of free ${ }^{125} \mathrm{I}$-transferrin (peak 2) was not demonstrated, the antibody exhibited clear specificity to- wards a reticulocyte component with intact transferrin-binding activity. Support for this finding was provided by the observation that IgG prepared from sheep serum after immunization inhibited ${ }^{59} \mathrm{Fe}$-transferrin uptake by reticulocytes but preimmune IgG did not (not shown).

Analysis of immunoprecipitates from reticulocyte extracts indicated that the ovine antibody specifically recognizes a single protein species, with an $M_{\mathrm{r}}$ of 90,000-100,000 (Figs. 2 and3). In radioautographs and gels stained for protein and run under reducing conditions, this polypeptide is coincident with bona fide transferrin receptor prepared by affinity chromatography. Heavy chains of immunoglobulin from the immunoprecipitates are seen in stained gels at an $M_{\mathrm{r}}$ of 55,000. Although the presence of abundant native immunoglobulin $\left(M_{\mathrm{r}}=160,000\right)$ precludes analysis of the material without addition of reducing agents, protein co-migrating with unreduced dimeric receptor, $M_{r}$ $\sim 190,000$, was detected in eluates from columns of immobilized antibody after electrophoresis under nonreducing conditions (data not shown). The stained gel displayed in Fig. 2 also shows that precipitation of the receptor polypeptide is independent of the presence of transferrin because addition of the protein did not affect subsequent retrieval of receptor in the second stage of the immunoprecipitation. Although there was considerable variation in the apparent migration of the polypeptide recognized by antibody, the immunoreactive species was always coincident with receptor subunits obtained by ligand-affinity chromatography and electrophoresed in parallel.

The antibody also detected a radioactive protein, $M_{\mathrm{r}}$ $\sim 90,000$, in extracts of reticulocytes labeled metabolically with L- $\left[{ }^{35}\right.$ S $]$ methionine (Fig. 3). The ${ }^{35} \mathrm{~S}$-labeled protein is coincident with the single ${ }^{125} \mathrm{I}$ species identified in surface-labeled cells by the same antibody. Electrophoresis of crude stromal extracts as shown in this gel indicated that the transferrin receptor accounts for a significant fraction of the ${ }^{35} \mathrm{~S}$ label incorporated into reticulocyte membrane proteins. The radioactivity in the receptor moiety was drastically reduced in immunoprecipitates derived from extracts of cells treated with $40 \mu \mathrm{g} / \mathrm{ml}$ cycloheximide to inhibit protein synthesis. Total cellular protein synthesis was inhibited by $82 \%$ at this concentration of cycloheximide.

To determine whether the newly synthesized receptor is ca-

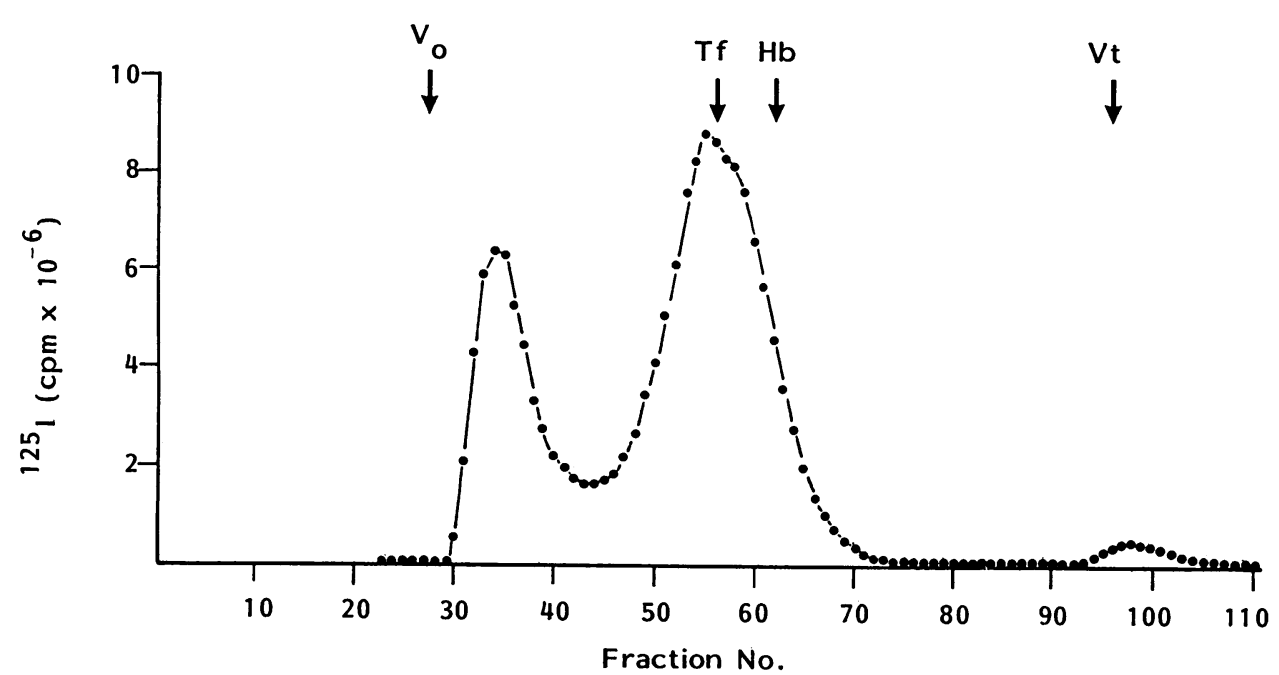

Figure 1. Gel-permeation chromatography of reticulocyte extract. Reticulocytes were incubated with ${ }^{125} \mathrm{I}$ transferrin (Tf) as described in Methods, and, after lysis with Triton $\mathrm{X}-100,1 \mathrm{ml}$ of $30,000-\mathrm{g}$ supernatant $\left(180 \times 10^{6} \mathrm{cpm}\right)$ was applied to a column $(1.6 \times 69.5 \mathrm{~cm})$ of Sephadex G-200 equilibrated in $0.01 \mathrm{M}$ Hepes, $0.13 \mathrm{M} \mathrm{NaCl}$, and $0.1 \% \mathrm{wt} / \mathrm{vol}$ Triton $\mathrm{X}-100, \mathrm{pH}$ 7.4. The column was eluted with the same buffer at a flow rate of $18 \mathrm{ml} / \mathrm{h}$ at $4^{\circ} \mathrm{C}$; fractions of $1.5 \mathrm{ml}$ were collected and counted for ${ }^{125} \mathrm{I}$. The column was calibrated with Dextran Blue (Vo, void volume) and ${ }^{125} \mathrm{I}-\mathrm{Tf}$. The elution positions of rabbit hemoglobin $(\mathrm{Hb})$ and the bed volume $(\mathrm{Vt})$ are also shown. Recovery of ${ }^{125} \mathrm{I}$ in the eluate exceeded $90 \%$ of the sample radioactivity. 
Table I. ${ }^{125}$ I-Radioactivity Bound by Ovine IgG-Sepharose

\begin{tabular}{cll}
\hline & Preimmune & Immune \\
\hline & $\%$ & $\%$ \\
Peak 1 $(\mu$ l applied $)$ & & \\
2 & 2 & 44 \\
4 & 5 & 67 \\
20 & 0 & 62 \\
Peak 2 & & \\
4 & 0 & 9 \\
20 & 0 & 0 \\
\hline
\end{tabular}

Aliquots of fractions obtained after gel filtration of reticulocyte extracts (labeled with ${ }^{125}$ I-transferrin) on Sephadex G-200 were applied to columns of IgG-Sepharose as in Methods. After washing, the percentage of ${ }^{125}$ I-transferrin retained was determined.

pable of binding transferrin, an extract of $1 \mathrm{ml}$ reticulocytes was prepared after labeling for $4 \mathrm{~h}$ in the presence of L$\left[{ }^{35} \mathrm{~S}\right]$ methionine and applied to a $1-\mathrm{ml}$ column of transferrinSepharose gel. The procedure for affinity purification of receptor was followed as described in Methods. After elution and concentration of the protein specifically bound by the gel, the material was electrophoresed together with a sample of crude extract and subjected to radioautography (Fig. 3). A faint and diffuse band of labeled protein coincident with the transferrin receptor moiety was detected in the eluted material.

To localize the cellular site of metabolically labeled receptor, two membrane fractions were prepared from reticulocytes after



Figure 2. Immunoprecipitation of reticulocyte protein. Stromal membranes from $100 \mu$ l packed reticulocytes (25\%) were extracted with Triton X-100 as described in Methods, and high-speed supernatant was treated with either $215 \mu \mathrm{g}$ preimmune ovine $\mathrm{IgG}$ or $195 \mu \mathrm{g}$ immune IgG raised against transferric receptor. Rabbit transferrin $(0.5$ $\mathrm{mg} / \mathrm{ml}$ ) was then added to the immunoprecipitation mix, as shown. Immunoprecipitates obtained after addition of affinity purified antisheep IgG in the presence of $3 \% \mathrm{wt} / \mathrm{vol}$ polyethylene glycol to ensure complete precipitation of all species of immune complex, were extensively washed and subjected to electrophoresis. Molecular weight markers, and biochemically purified transferrin receptor were also electrophoresed and the gel was stained with Coomassie Brilliant Blue. $\mathrm{K}, 1,000$.

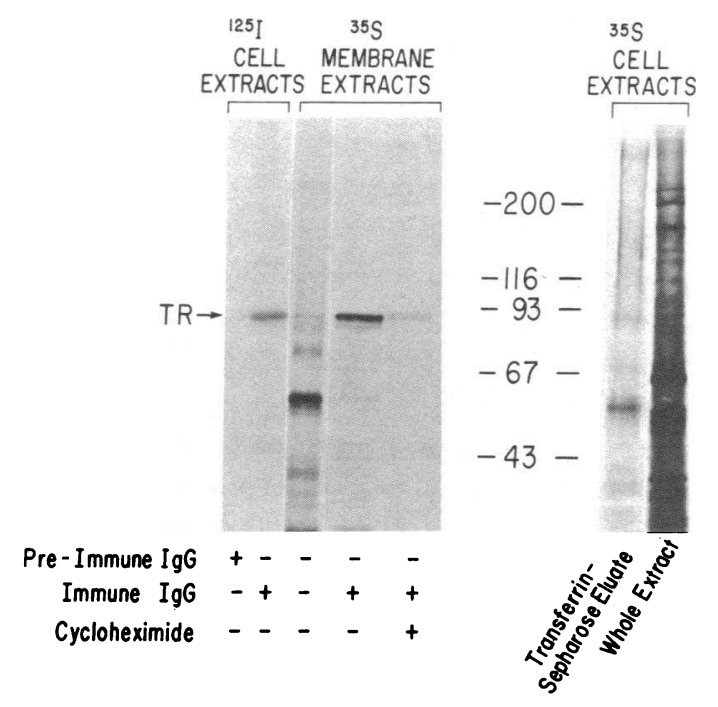

Figure 3. Detection of radiolabeled transferrin receptor. Reticulocytes (35\%) were surface labeled with ${ }^{125} \mathrm{I}$ in situ $\left(1.4 \times 10^{6} \mathrm{cpm}\right.$ incorporated per $50 \mu$ l packed cells) or metabolically labeled for $3 \mathrm{~h}$ with L$\left.{ }^{35} \mathrm{~S}\right]$ methionine $\left(2.5 \times 10^{7} \mathrm{cpm} / 25 \mu \mathrm{l}\right)$ with or without the addition of $40 \mu \mathrm{g} / \mathrm{ml}$ cycloheximide. Incorporation of ${ }^{35} \mathrm{~S}$ into cycloheximidetreated cells was $0.47 \times 10^{7} \mathrm{cpm}$. Transferrin receptor was retrieved by immunoprecipitation with specific antibody or affinity chromatography and analyzed by electrophoresis under reducing conditions and by radioautography as described in Methods. ${ }^{35} \mathrm{~S}$ in samples was detected after fluorographic enhancement. The position of purified receptor protein (detected by staining with Coomassie Blue) is shown by the arrow and designated TR. Electrophoretic tracks included untreated extracts of reticulocyte membranes or whole cells labeled with ${ }^{35} \mathrm{~S}$, as indicated. Reticulocytes after surface labeling with ${ }^{125} \mathrm{I}$ were solubilized and treated with preimmune or antireceptor IgG, and immunoprecipitates from these whole extracts were subjected to electrophoresis.

incubation for $2 \frac{1}{2} \mathrm{~h}$ with $\mathrm{L}-\left[{ }^{35} \mathrm{~S}\right]$ methionine with or without the addition of exogenous hemin. After hypotonic lysis with $\mathrm{H}_{2} \mathrm{O}$, membrane pellets were prepared by centrifugation for $20 \mathrm{~min}$ at $10,000 \mathrm{~g}$ and then by centrifuging the resulting supernatant for a further $60 \mathrm{~min}$ at $100,000 \mathrm{~g}$. The membrane pellets were solubilized in detergent and again subjected to centrifugation at high speed. The electrophoretic analysis by radioautography of the membrane extracts after treatment with receptor antibody is shown in Fig. 3. Radiolabeled receptor was identified only in the 10,000-g membrane pellet. The two tracks represent the effects of treatment of the cells with $50 \mu \mathrm{M}$ hemin in addition to diferric transferrin (Fig. 4). In the presence of transferrin, and therefore presumably with adequate intracellular heme, exogenous hemin did not appreciably affect receptor synthesis.

Accordingly, the effect of intracellular heme deficiency on synthesis of protein overall, and particularly of the transferrin receptor, was investigated (Fig. 5). Reticulocytes were harvested after passage over cellulose and labeled with L- $\left[{ }^{35}\right.$ S $]$ methionine. Intracellular heme deficiency was induced by incubating one sample with 4,6 dioxoheptanoate to inhibit delta aminolevulinic acid dehydratase competitively. At the concentration used, iron incorporation from transferrin into cellular heme was inhibited markedly (15), as has been confirmed in this laboratory. To overcome the effects of the inhibitor on intracellular heme, hemin $(50 \mu \mathrm{M})$ was added to the third sample of cells. At intervals, 
Immunoprecipitated ${ }^{35} \mathrm{~S}$-labeled Membrane Extracts

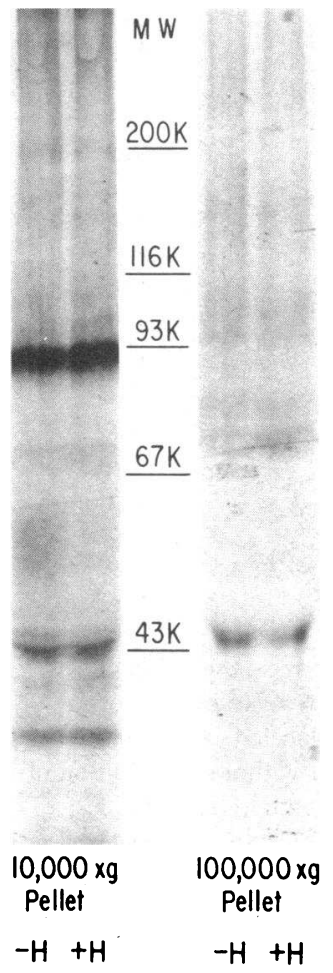

crease in incorporation of radiolabel into cellular protein. Addition of exogenous hemin overcame the influence of dioxoheptanoate, allowing recovery of protein synthesis. Control rates of receptor synthesis were also restored when dioxoheptanoatetreated cells were supplemented with exogenous hemin.

\section{Discussion}

Erythroid precursor cells require large amounts of iron for the formation of heme and thus express transferrin receptors on their surface throughout development (18). During maturation the number of receptors changes (19), such that functional receptors are absent from the surface of mature erythrocytes. Although reticulocytes are anucleate, they continue to synthesize a variety of proteins (20) and contribute up to $30 \%$ of the hemoglobin complement of the mature erythrocyte (21). In this study, immunochemical techniques, employing specific antibody to denatured receptor, were used to determine whether reticulocytes synthesize the transferrin receptor. Observations are presented that indicate that this antibody recognized functionally intact receptors expressed on the cell surface. The use of reticulocytes made it possible to determine whether the biosynthesis of transferrin receptors reflects the operation of the heme-regulated control of protein synthesis in immature erythroid cells (6-8)

Experiments carried out with different reticulocyte preparations consistently showed that this cell retains the capacity to synthesize transferrin receptor and insert newly made receptor into stromal membranes. The structural characteristics of the labeled receptor recognized by our antibody are in accord with previous analyses of transferrin receptors detected in cultured human cells $(22,23)$, human placenta $(24)$, and human $(25)$ or rabbit reticulocytes $(26,27)$. Quantitative studies indicated that incorporation of radiolabeled methionine into the receptor moiety accounted for $0.1-0.2 \%$ of the labeled cellular protein. Analysis of membrane extracts showed, moreover, that the receptor accounted for a significant fraction of the ${ }^{35} \mathrm{~S}$ incorporated

aliquots of reticulocytes were removed for measurement of total protein synthesis and for immunoprecipitation of receptor. Each sample of extract was analyzed for radioactivity specifically incorporated into cellular receptors. These data indicate that depletion of intracellular heme progressively diminishes reticulocyte protein synthesis and synthesis of receptor. The extent of inhibition of receptor synthesis appears to exceed the global de-

Figure 5. Influence of intracellular heme deficiency on receptor synthesis. Reticulocytes $(20 \%)$ obtained after passage over cellulose were incubated in nutritional medium containing $\mathrm{L}-\left[{ }^{35} \mathrm{~S}\right]$ methionine $(1.2 \mathrm{mCi} /$ $\mathrm{ml}$ cells) at a final concentration of $10 \mu \mathrm{M}$ as in Methods. The control incubation contained $1 \mathrm{mg} / \mathrm{ml}$ transferrin alone: 4,6:dioxoheptanoate $(500 \mu \mathrm{M})$ was added to inhibit heme formation and $50 \mu \mathrm{M}$ aqueous hemin was added to replete the inhibited cells. Aliquots were removed for determination of TCA-insoluble radioactivity $(A)$, and at 1,2 , and 4 $\mathrm{h}$, two samples, representing $100 \mu \mathrm{l}$ $\left(10^{9}\right)$ cells, were taken for solubilization from each incubation $(B)$. Radioactivity in immunoprecipitated transferrin receptor was determined at each point by correction for interstitial radioactivity in identical precipitates containing preimmune ovine IgG. 
into stromal proteins. The possibility that metabolic labeling with ${ }^{35} \mathrm{~S}$-methionine represented not de novo synthesis but posttranslational incorporation of radiosulfur into the glycoprotein is rendered unlikely by the observation that cycloheximide, which inhibits peptide bond formation, profoundly reduced radiolabeling of the receptor moiety.

Although globin is the protein synthesized in greatest quantity by immature erythroid cells, appreciable amounts of nonglobin protein are also produced. Careful analysis of protein synthesized by intact reticulocytes has shown that $\sim 15 \%$ of the incorporated radioactive aminoacids may be found in nonglobin polypeptides (28). Nonglobin proteins in reticulocytes are synthesized predominantly on membrane-bound polyribosomes that sediment at low centrifugal forces (29). The observation that the newly made transferrin receptor was only detectable in extracts of membranes sedimenting at $10,000 \mathrm{~g}$ is thus compatible with the expected synthetic site of nonglobin polypeptides. Investigations of translation of mRNAs for secretory and membrane proteins in cell-free systems have demonstrated that supplementation with microsomes allows normal processing of the nascent proteins to occur. Proteolytic cleavage and glycosylation proceed cotranslationally and are generally accompanied by translocation of the nascent chains across microsomal membrane vesicles, where they become segregated (30). The finding that radiolabeled transferrin receptor may be detected in reticulocyte membranes, and may acquire functional binding activity, indicates that these cells retain the complex mechanism for vectorial insertion across membranes as well as the enzymic activities required for processing. It is conceivable that the antibody used in these studies failed to recognize nascent receptor in extracts of free ribosomes, but the polyclonal nature of the xeno-antiserum raised after persistent antigenic challenge renders this possibility unlikely. Thus, synthesis of nascent protein on membrane-bound polyribosomes with co-translational insertion into the plasmalemma appears to be the process by which reticulocytes produce mature transferrin receptor.

Reticulocytes do not possess nuclei and do not synthesize RNA; since they actively synthesize a variety of proteins, these cells, or extracts prepared from them, provide an excellent system for studies of translational control. Synthesis of $\alpha$ - and $\beta$-globin chains is dependent on the presence of heme in intact cells or cell-free lysates to maintain the heme-regulated eIF- $2 \alpha$ protein kinase in its inactive form (5). Previous studies indicate that there is considerable variation in the intrinsic ability of reticulocyte mRNAs to direct initiation, particularly under conditions of heme deficiency $(8,31,32)$.

In heme deficiency, the heme-regulated eIF- $2 \alpha$ kinase is activated, elF- $2 \alpha$ is phosphorylated, a nondissociable complex of eIF-2(P) and the recycling factor is formed, and recycling factor becomes limiting in the initiation of protein synthesis (33). As a result, the recycling of eIF-2 is inhibited, the formation of the ternary complex (eIF-2 - Methionyl-tRNA $\cdot$ GTP) is inhibited, and the formation of the complex of the $40 \mathrm{~S}$ ribosomal subunit with the ternary complex is diminished. When $40 \mathrm{~S} \cdot$ Met-tRNA complex formation is diminished, the translation of various mRNAs will vary depending on their amounts and on their affinity for the $40 \mathrm{~S} \cdot$ Met-tRNA $_{\mathrm{f}}$ complex; for example, in heme deficiency, the translation of $\alpha$-globin mRNA is much more inhibited than that of $\beta$-globin mRNA, because of the greater affinity of the $\beta$-globin mRNA for the $40 \mathrm{~S}$-Met-tRNA $\mathrm{f}_{\mathrm{f}}$ complex (32). Accordingly, having demonstrated biosynthesis of the transferrin receptor in intact reticulocytes, we addressed the fur- ther question of the extent to which synthesis of the receptor is affected by intracellular heme deficiency. The results indicate that synthesis of the receptor is significantly inhibited when the concentration of intracellular heme is diminished by the inhibition of heme synthesis (Fig. 5).

Recent studies in cultured human K562 erythroleukemia cells yield a half-life value for the transferrin receptor of $7 \mathrm{~h}$, and induction of iron deficiency in these cells by desferrioxamine leads to increased expression of the receptor by enhancing transcription of receptor mRNA (34). Since iron deficiency should result in heme deficiency, the question is raised of the operation of the heme-regulated eIF- $2 \alpha$ kinase mechanism in K562 cells. It is known that this mechanism is present in human reticulocytes (35), but it remains to be determined whether it is operative in normal nucleated erythroid cells of the marrow or in K 562 cells. There is the speculative possibility that in early stages of erythroid cell development, transcriptional control of transferrin receptor synthesis predominates, but that as maturation progresses and nuclear function declines, translational control supervenes. This possibility may appear unlikely, but it merits investigation.

\section{Acknowledgments}

This work was supported by a Senior Clinical Wellcome Research Fellowship to Dr. Cox, and by U. S. Public Health Service grants AM-16272 and $\mathrm{AM}-15056$.

\section{References}

1. Jandl, J. H., and J. Katz. 1963. The plasma-to-cell cycle of transferrin. J. Clin. Invest. 42:314-336.

2. Walsh, R. J., E. D. Thomas, S. K. Chow, R. G. Fluharty, and C. A. Finch. 1949. Iron metabolism. Heme synthesis in vitro by immature erythrocytes. Science (Wash. DC). 110:396-398.

3. Jandl, J. H., J. K. Inman, R. L. Simmons, and D. W. Allen. 1959. Transfer of iron from serum iron-binding protein to human reticulocytes. J. Clin. Invest. 38:161-185.

4. Bruns, G. P., and I. M. London. 1965. The effect of hemin on the synthesis of globin. Biochim. Biophys. Res. Commun. 18:236-242.

5. Levin, D. H., R. S. Ranu, V. Ernst, and I. M. London. 1976. Regulation of protein synthesis in reticulocyte lysates: phosphorylation of methionyl-tRNA $f$ binding factor by protein kinase activity of the translational inhibitor isolated from heme-deficient lysates. Proc. Natl. Acad. Sci. USA. 73:3112-3116.

6. Matts, R. L., D. H. Levin, and I. M. London. 1983. Effect of phosphorylation of the alpha-subunit of eukaryotic initiation factor 2 on the function of reversing factor in the initiation of protein synthesis. Proc. Natl. Acad. Sci. USA. 80:2559-2563.

7. Beuzard, Y., R. Rodvien, and I. M. London. 1973. Effect of hemin on synthesis of hemoglobin and other proteins in mammalian cells. Proc. Natl. Acad. Sci. USA. 70:1022-1026.

8. Lodish, H., and O. Desalu. 1973. Regulation of synthesis of nonglobin proteins in cell-free extracts of rabbit reticulocytes. J. Biol. Chem. 248:3520-3527.

9. Beutler, E., C. West, and K.-G. Blume. 1976. The removal of leukocytes and platelets from whole blood. J. Lab. Clin. Med. 88:328333.

10. Baker, E., D. C. Shaw, and E. H. Morgan. 1968. Isolation and characterization of rabbit serum and milk transferrins. Evidence for difference in sialic acid content only. Biochemistry. 7:1371-1378.

11. Bensadoun, A., and D. Weinstein. 1976. Assay of proteins in the presence of interferring materials. Anal. Biochem. 70:241-250.

12. Bruck, C., D. Portetelle, C. Glineur, and A. Bollen. 1982. One- 
step purification of mouse monoclonal antibodies from ascitic fluid by DEAE-Affi-Gel Blue chromatography. J. Immunol. Methods. 53:313319.

13. Ouchterlony, O. 1958. Diffusion-in-gel methods for immunological analysis. Prog. Allergy. 5:1-78.

14. Ranu, R. S., and I. M. London. 1979. Regulation of protein synthesis in rabbit reticulocyte lysates: preparation of efficient protein synthesis lysates and the purification and characterization of the hemeregulated translational inhibitory protein kinase. Methods Enzymol. 60: 459-484.

15. Ponka, P., A. Wilczynska, and H. M. Schulman. 1982. Iron utilization in rabbit reticulocytes. A study using succinylacetone as an inhibitor of heme synthesis. Biochim. Biophys. Acta. 720:96-105.

16. Marchalonis, J. J. 1969. An enzymatic method for the trace iodination of immunoglobulin and other proteins. Biochem. J. 113:299305.

17. Laemmli, U. K. 1970. Cleavage of structural proteins during the assembly of the head of bacteriophage $T_{4}$. Nature (Lond.). 227:680-685.

18. Nunez, M. T., J. Glass, S. Fischer, L. M. Lavidor, E. M. Lenk, and S. H. Robinson. 1977. Transferrin receptors in developing murine erythroid cells. Br. J. Haematol. 36:519-526.

19. Iacopetta, B. J., E. H. Morgan, and G. C. T. Yeoh. 1982. Transferrin receptors and iron uptake during erythroid cell development. Biochim. Biophys. Acta. 687:204-210.

20. Lodish, H. F., B. Small, and H. Chang. 1975. Maturation of rabbit reticulocytes: degradation of specific reticulocyte proteins. Dev. Biol. 47:59-67.

21. Papayannopoulou, T., and C. A. Finch. 1975. Radioiron measurements of red cell maturation. Blood Cells. 1:535-546.

22. Trowbridge, U. S., and M. B. Omary. 1981. Human cell surface glycoprotein related to cell proliferation is the receptor for transferrin. Proc. Natl. Acad. Sci. USA. 78:3039-3043.

23. Schneider, C., R. Sutherland, R. Newman, and M. Greaves. 1982. Structural features of the cell surface receptor for transferrin that is recognized by the monoclonal antibody OKT9. J. Biol. Chem. 257:85168522.

24. Seligman, P. A., R. B. Schleicher, and R. H. Allen. 1979. Isolation and characterization of the transferrin receptor from human placenta. J. Biol. Chem. 254:9943-9946.

25. Enns, C. A., and H. H. Sussman. 1981. Similarities between the transferrin receptor proteins on human reticulocytes and human placentae. J. Biol. Chem. 256:12620-12633.

26. Leibman, A., and P. Aisen. 1977. Transferrin receptor of the rabbit reticulocyte. Biochemistry. 16:1268-1272.

27. Witt, D. P., and R. C. Woodworth. 1978. Identification of the transferrin receptor of the rabbit reticulocyte. Biochemistry. 17:39133917.

28. Bulova, S., and E. R. Burka. 1970. Biosynthesis of nonglobin protein by membrane-bound ribosomes in reticulocytes. J. Biol. Chem. 245:4907-4912.

29. Schieml, W., and E. R. Burka. 1968. Properties of membranebound ribosomes in reticulocytes. J. Biol. Chem. 243:3573-3580.

30. Shields, D., and G. Blobel. 1978. Efficient cleavage and segregation of nascent presecretory proteins in a reticulocyte lysate supplemented with microsomal membranes. J. Biol. Chem. 253:3753-3756.

31. Boyer, S. H., K. D. Smith, A. N. Noyes, and M. A. Mullen. 1974. Immunological characterization of rabbit hemoglobin alpha and beta chain synthesizing polysomes. J. Biol. Chem. 249:7210-7219.

32. Beuzard, Y., and I. M. London. 1974. The effects of hemin and double-stranded RNA on alpha and beta glogin synthesis in reticulocyte and Krebs II ascites cell-free systems and the reversal of these effects by an initiation factor preparation. Proc. Natl. Acad. Sci. USA. 71:28632866.

33. Matts, R. L., D. H. Levin, R. Petryshyn, N. S. Thomas, and I. M. London. 1984. Translational control of protein synthesis in reticulocyte lysates by eIF-2 $\alpha$ kinases. In Mechanisms of Protein Synthesis. E. Bermek, editor. Springer-Verlag, Berlin-Heidelberg. 144-158.

34. Mattia, E., K. Rao, D. S. Shapiro, H. H. Sussman, and R. D. Klausner. 1984. Biosynthetic regulation of the human transferrin receptor by desferrioxamine in K562 cells. J. Biol. Chem. 259:2684-2692.

35. Petryshyn, R., F. Rosa, R. Fagard, D. Levin, and I. M. London. 1984. Control of protein synthesis in human reticulocytes by heme-regulated and double-stranded RNA dependent eIF- $2 \alpha$ kinases. Biochem. Biophys. Res. Commun. 119:892-899. 